\title{
An exploration of the symbolic world of Proverbs 10:1-15:33 with specific reference to 'the fear of the Lord'
}

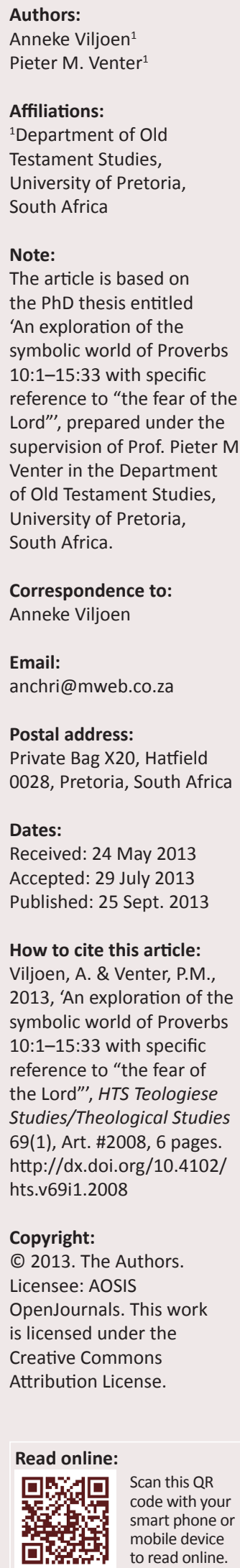

Alternative approaches to text interpretation have introduced an opportunity to understand the biblical text afresh. One such an alternative approach is a Ricoeurian hermeneutic. Ricoeur's understanding of the referential intention of poetic texts will be drawn on to explore its interpretive contribution to a reading of Proverbs 10:1-15:33 with specific reference to the phrase 'the fear of the Lord'. It is suggested that the proposed reading strategy is a most productive effort.

\section{Introduction}

The postmodern milieu introduces largely unexplored opportunities for Old Testament studies to probe the interpretive contribution that alternative reading strategies present contemporary readers of the Bible. Brueggemann (2003:xi) notes how developments in the interpretive perspective of Old Testament study have made a difference to the way in which the Old Testament may be accessed as a source and norm for faith. The emergence of alternative approaches to and methods of text interpretation that stand alongside historical criticism have introduced an opportunity to understand the biblical text and faith concepts, such as 'the fear of the Lord' expressed in the text, afresh.

One such an alternative approach to text interpretation is represented by a Ricoeurian hermeneutics. Ricoeur's understanding of the referential intention of poetic texts will be drawn on to explore the interpretive contribution it can make to a reading of 'the fear of the Lord'proverbs in Proverbs 10:1-15:33. A sample proverb from each chapter in which the fear of the Lord'-proverbs occur in this collection will serve as a case study.

\section{Ricoeur's understanding of the referential intention of poetic texts}

For Ricoeur (1976:2-6) modern linguistics' achievements, as a result of the fundamental distinction of Ferdinand de Saussure between language as langue as opposed to language as parole, focused greatly on an understanding of language as langue and not on language as parole. Thus, the focus of modern linguistics was on langue, the code or set of codes or the sense of a text, on the basis of which a particular speaker produces parole, as a particular message. One of his aims with the project, Interpretation theory: Discourse and the surplus of meaning, was 'to rescue discourse from its marginal and precarious exile' (Ricoeur 1976:2).

According to Ricoeur (1976):

... it appears as if every discourse can be investigated in terms of both its internal organization, which makes it a message, which can be identified and reidentified, and its referential intention, which is its pretention to say something about something. (p. 66)

It is on the level of the sentence, from where discourse ensues, that the inner or immanent constitution of the sense is related to the outer or transcendent intention of the reference (Ricoeur 1976:22). Ricoeur (1976) explains:

To refer is what the sentence does in a certain situation and according to a certain use. It is also what the speaker does when he applies his words to reality. That someone refers to something at a certain time is an event, a speech event. But this event receives its structure from the meaning as sense. The speaker refers to something on the basis of, or through, the ideal structure of the sense. The sense so to speak is traversed by the referring intention of the speaker. (p. 20)

The sense is the pure predicative relation while the reference is its pretention to say something about reality, in short, its truth value (Ricoeur 1976:66).

Meaning is generated, according to Ricoeur, on two levels, and poetic texts can only be fully understood if they are investigated in terms of both these levels. Poetic texts are, for Ricoeur, 
literary texts that have the ability to open up a view of a possible world that eclipses the tangible, objective world (Ricoeur 1977:26). They are imaginative literary constructions that by virtue of the refiguration of possibilities reconstruct reality and invite the reader to inhabit this projected world by adopting those refigured possibilities as his or her own (Hall 2006:193). This notion will be considered with specific reference to the fear of the Lord in Proverbs 10:1-15:33. What a Ricoeurian hermeneutical enquiry aims for is not just to understand the inner constitution of the sense, or the 'what is said'; it also wants to come to an understanding of the outer intention of the reference, or that 'about what it is said'.

For Ricoeur, an explanation of the text's linguistic sense is just one stage of a hermeneutical enquiry. There is also the possibility of understanding the text in terms of its metaphorical intention or the symbolic world referenced by the text. Consequently, both the internal organisation (under the heading: "The "what is said" and proverb poetics or "how it is said"') of the sample proverbs in Proverbs 10:1-15:33 that make reference to 'the fear of the Lord', as well as their referential intention (under the heading: 'The symbolic world referenced or the "about what it is said"') will come into consideration in this article. Barton's (1996:205) definition of poetics is helpful: 'A poetics is an attempt to specify how literature "works", how it enables us to perceive the meanings we do perceive in it.'

\section{Exploring the symbolic world of Proverbs 10:1-15:33 with specific reference to 'the fear of the Lord'}

In this section the 'what is said' and the 'about what it is said' of three 'fear of the Lord'-proverbs will be studied (Pr 10:27, 14:26, and 15:16 respectively). The 'about what it is said' takes the 'what is said' one step further in order to discern the symbolic textual world that is referenced by the text, so that the reader may inhabit that world as her or his own.

\section{The 'what is said' and proverb poetics or 'how it is said' of Proverbs 10:27}

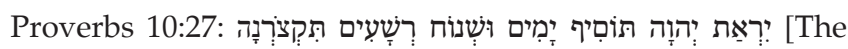
fear of Yahweh will cause to increase days but the years of the wicked will be shortened]. ${ }^{1}$

The prospect or future expectancy of life or of death, both expressed by the imperfect verb, is used within a rhetoric of the desirable (a lengthening of days) and a rhetoric of the undesirable (the shortening of years) respectively, combined with cause and effect-/act-consequence rhetoric (bringing into play thoughts of divine activity) as a motivation to persuade the reader of the value of the fear of the Lord (cf. Sandoval 2006:174-180). The proverb plays metaphorically on the patriarchal covenant tradition with its promise of long life.

1. Hebrew quotations in this article are from Biblia Hebraica Stuttgartensia; English translations are the author's.

\section{The symbolic world referenced or the 'about what it is said' of Proverbs 10:27}

This proverb references a world in which Yahweh is a determining factor to be reckoned with. Fearing the Lord or its antithesis, being wicked, has an effectual outcome in a person's life, suggested by the causative תiأםبיף (hiph'il). The fear of Yahweh increases the days of the righteous-wise, whereas the years of the wicked-fools will be shortened.

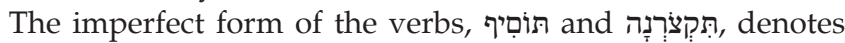
a dimension of future expectancy. The symbolic world of Proverbs is a stable predictable world, one in which the outcome of attitudes and behaviours can be predicted (cf. Frydrych 2002:170).

This could be read as indicating a deterministic, automatic and mechanical world where a person through his or her own character and actions determines his or her future, either positive or negative. Yet, the passive verb in the

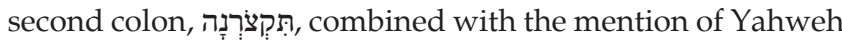
in the first, hints at divine activity. This indirect way of referencing divine activity alludes to a world in which Yahweh is actively involved, determining the appropriate consequences (cf. Frydrych 2002:106), though often operative in the background. In this world Yahweh is the guarantor of just rewards (Boström 1990:217).

The antithetical structure of the proverb is a literary expression of the symbolic-textual world that the proverb sketches (cf. Loader 1986:107-110). The human world is for Proverbs bifurcated between the righteous-wise and the wicked-fools (Ansberry 2010:162). These are in antithetical opposition to each other, and for Proverbs there is no other category. This proverb diverges from the use of the expected vocabulary with רָָָָע [the wicked] being contrasted with the fear of Yahweh; normally, it stands in opposition to [righteous]. This implies that in the symbolic-textual world of Proverbs there is a contingent relationship between righteousness and the fear of the Lord, and conversely, between wickedness and not fearing Yahweh (this is also evident from Pr 14:2).

Within the literary context of this cluster, these proverbs together outline a sense of positive future expectancy for the righteous-wise. Various scholars group verses 27-30 together (Garrett 1993:122; Ironside 2006:74), whilst others group verses 27-32 into a single unit (Murphy 1998:76; Engelbrecht 1978:6). Heim (2001:131) designates the cluster to range from verses 23-30 with two main sections, (1) verses 23-25 and (2) $27-30$, separated by verse 26 . The immediate literary context seems to be best identified as verses $27-30$.

The sense of positive future expectancy for the righteouswise in this cluster of proverbs finds expression in verse 27 in increase of days, in verse 28 hope brings joy, in verse 29 the way of the Lord is a stronghold (just as the fear of the Lord is in 14:26), and in verse 30 the righteous will never be removed from the land. The first and last verse of the cluster both remind of the familiar covenantal promise of a long life and inheritance of the land. In this way the proverb references the patriarchal covenant tradition (cf. Heim 
2001:132). The proverbial wisdom tradition is through the use of the personal name Yahweh, very specifically linked to the rest of the Old Testament tradition (cf. Bullock 2009:11; Dell 2006:149; Frydrych 2002:89). The symbolic-textual world that Proverbs constructs for its readers references the world of the patriarchs and Israel.

The converse of the positive future expectancy for the righteous-wise is a negative future expectancy for the wickedfool: shortening of years in verse 27 , perishing expectation in verse 28 , destruction to evildoers in verse 29 and no dwelling in the land in verse 30 . The severity of the repercussions for the wicked that do not fear Yahweh is in this proverb indicated by the years being shortened as opposed to the lengthening of days. This is suggestive of the high regard for, and due to, Yahweh in the proverbial world. An offensive attitude (and resultant behaviour) toward the deity, rightly and justly, merits a severe rebuke.

The experience of the righteous-wise and wicked-fools of Yahweh in the proverbial textual world is quite different. For the righteous-wise the Lord is protection and security whereas for the wicked-fool destruction. This indicates that the relationship between Yahweh and a person in the symbolic-textual world of Proverbs is reciprocal (Boström 1990:220). Fear of Yahweh is met with a positive response, in this case an increase of days, and wickedness with a negative reaction, in this case a shortening of years. It can be concluded that in the symbolic-textual world that Proverbs references for its reader, Yahweh is to be reckoned with.

\section{The 'what is said' and proverb poetics or 'how it is said' of Proverbs 14:26}

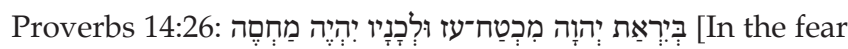
of Yahweh the trust of strength and for his children he will be a place of refuge].

The proverb sketches the fear of Yahweh metaphorically as a place of refuge, utilising the symbolic value of the spatial dimension that is created by the combination of the

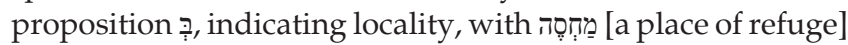
as a metaphor for safety. It diverges from the expected pattern of antithesis and is grafted in a synonymous parallelism, expressing the flow of the benefit of wisdom from one generation to the next as the proverb flows from colon $\mathrm{A}$ to colon B. The subject of the second colon remains uncertain as it could be the parent or Yahweh. The benefit of wisdom does not come to the children without the parent, but through the parent that finds a strong confidence in Yahweh, making both the parent and Yahweh the place of refuge for the next generation. The proverb declares that in the fear of Yahweh one may find surety of strength and invites the reader to place his or her trust in it, to the benefit of oneself and one's offspring.

\section{The symbolic world referenced or the 'about what it is said' of Proverbs 14:26}

This verse, through sketching the fear of Yahweh metaphorically as a place of refuge, glimpses the symbolic- textual world of Proverbs in which the fear of Yahweh is a very tangible protection (cf. Pr 18:10). There is no doubt that the proverb testifies to something that Proverbs considers to be very real (cf. Frydrych 2002:93).

The intangible reality of the fear of the Lord is sketched as a very real place of refuge in which the righteous-wise can confidently place their trust and find safety. Heim (2001:186) notes that when the verb בּטָָ [feel safe or trust] is being used in the Old Testament in a positive sense, God is almost invariably the object of trust. The immense trust that the sages had in the Lord to provide safety and security for those who fear Yahweh is reinforced and finds further expression in the metaphoric reference to the place of refuge in the second colon.

The diversion from the expected pattern of antithetic parallelism that is so common in 10:1-15:33 marks this proverb as notable. It is instead constructed in synonymous parallelism that textually expresses the flow of the benefit of the fear of Yahweh from one generation to the next in the symbolic-textual world of Proverbs, as the proverb flows from colon A to colon B. Boström (1990:217; cf. also 220) notices in the proverb's reference to the children of the fearer of Yahweh that the seeming individualism of wisdom is not a strictly defined view. Through the proverb the reader glimpses a world in which the protection that the fear of Yahweh provides is extended to one's family.

How this happens is not specified in the proverb. The subject of the second colon remains uncertain: it could be either the parent, or Yahweh, or both that are the refuge of the children. In the proverbial world that the proverb references the benefit of the fear of Yahweh may also come to the children through the parent, who finds a strong confidence in Yahweh, making both the parent and Yahweh the place of refuge for the next generation. This assurance is the ground for the proverb's appeal. The proverb simultaneously declares that in the fear of Yahweh one may find surety of strength and confidence in safety and invites the reader to place his or her trust in it, to the benefit of oneself and one's offspring.

This is not a foreign idea to the Old Testament but is also found outside the proverbial tradition, particularly in the Decalogue (Ex 20:6; Dt 5:10). In this way the proverb references the Mosaic tradition (cf. Ross 2008). It has already been noted that through the use of the personal name Yahweh, the proverbial wisdom tradition is very specifically linked to the rest of the Old Testament tradition. Again, as in Proverbs 10:27, this proverb establishes a connection with the extra-proverbial biblical tradition. The symbolic-textual world that Proverbs constructs for its readers references the world of Moses and the people of Israel.

\section{The 'what is said' and proverb poetics or 'how it is said' of Proverbs 15:16}

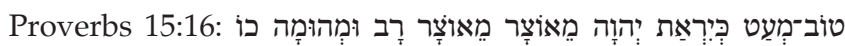
[Better a little in the fear of Yahweh than a great storehouse and panic in it]. 
This proverb utilises a rhetorical device that by the mismatching of the parallel lines enriches the message of the saying beyond the sum of its parts (Fox 2004:166). Two contrasts are being set up in this antithetic proverb. Firstly, the little is contrasted with a great storehouse. Secondly, the fear of Yahweh is contrasted with panic. Starting with the second contrast, the thought is that the storehouse is the cause of the panic. Fox (2009:595) translates turmoil in the sense of agitation and conflict as when brothers strife over an inheritance. By implication a little in the fear of the Lord comes with peace, whereas panic or turmoil accompanies abundant provisions that were gained with a lack of the fear of the Lord. When the fear of the Lord is set in antithesis with panic in this proverb, they are shown to be opposites (Fox 2009:595). Fear and panic usually go together, but the fear of the Lord is here revealed as something opposite to panic. A great storehouse promises peace of mind but may actually bring panic, whereas fear, when it is the fear of Yahweh, does not lead to panic but to the opposite, which is implied, namely peace.

The proverb teaches the worth of the fear of the Lord which is far more prized than something everyone desires, namely a great storehouse, even when it is paired with something less desirable, namely scarce provisions (cf. Fox 2009:597). Additionally, as Fox (2009:595) points out, the proverb teaches that turmoil is calamitous and arises from lack of the fear of God. To sum up: 'Material wealth is good, but other things are more important. Piety compensates for its lack, and turmoil cancels its value' (Fox 2009:595).

\section{The symbolic world referenced or the 'about what it is said' of Proverbs 15:16}

In this proverb, the economy of the symbolic-textual world of Proverbs comes into view. The value or worth of commodities is being assessed. The proverbial world is a world in which the relative value of commodities is evaluated against the backdrop of the effect or result thereof in the lives of the people possessing it. Here commodities or possessions have little value in themselves, but may have great or no worth depending on their effect on the human world. Thus, the proverb can declare that a little in the fear of Yahweh is better than a great storehouse and panic in it.

As mentioned in the previous section, the form of the proverb, being disjointed parallelism, is significant. The proverb, by its form, invites the reader to participate in its reasoning. Here the analytical nature of such proverbs becomes evident. Fox (2004) states:

If read carefully, then, the disjointed proverbs not only transmit packets of truths, they also train the reader in a mode of thinking: identifying behaviours and associating them with their consequences. In other words, they train the reader to think like a sage. (p. 176)

Imperfect or disjointed parallelism leaves a gap between the lines. When the missing component - a premise or a conclusion - is mentally supplied, the proverb persuades its reader to evaluate the values and experiences that are being encapsulated in the proverb (Fox 2009:598). Perry (in Fox 2009) propose the following evaluation of values, of which two are omitted in this proverb, marked from best to worse, with positive and negative values according to the speaker's implied value system:

1. $\left(\mathrm{A}^{\prime}\right)$ a great storehouse and $(\mathrm{B})$ fear of the Lord $(+/+)$

2. $\left(\mathrm{A}^{\prime}\right)$ a great storehouse and $\left(\mathrm{B}^{\prime}\right)$ turmoil $(+/-)$

3. (A) sparse food and (B) fear of the Lord $(-/+)$

4. (A) sparse food and (B') turmoil (-/-). (p. 598)

Through an assertion of relative value, the proverb negotiates the values of the proverbial world and the reader is encouraged and trained to think about and evaluate things and not just accept the worth that is given to commodities by society. Treier (2011:89), Fox (2009:595) and Clements (2003:451) note, in connection with this proverb, the underlying perspective of Proverbs concerning ultimate profit, namely, that the worth of the fear of Yahweh is valued above wealth.

This is especially true because of the resulting effect that the fear of Yahweh has on the person. By implication it supplies peace or inner joy. This is evident from the immediate literary context. Heim (2001:196-199) indicates that this proverb can be read as part of a cluster, ranging from Proverbs 15:13 to 15:18. The cluster is loaded with terms denoting emotions (Heim 2001:198) and references to a banquet and eating. Whybray ([1979] 1990:161) notes the close relation between verses 16 and 17 that is for him evident, not only from the contents of the two proverbs, but also from the parallelism of their form. His supposition that verse 16 elevates the thought of verse 17 to a religious plane is helpful, especially in the light of reading the proverb in its present canonical shape and context. Whybray ([1979] 1990:161) and Heim (2001:198-199) both note the influence that verse 16 has on the understanding of the surrounding proverbs. In this context the fear of Yahweh is identified as a source of inner peace.

The close relationship between the book of Proverbs and the Instruction of Amenemope, which is especially evident from Proverbs 15:16-17 and the Instruction of Amenemope 9.5-8, is notable:
5. Better is poverty in the hand of the god,
6. than wealth in the storehouse.
7. Better are (mere) loaves of bread when the heart is pleasant,
8. than wealth with vexation. (Fox 2009:596)

Which of the two works was first and influenced the other is by no means certain and the debate continues (for a discussion on the debate see Shupak 2005). However, the mere fact that there is such a close resemblance between the two writings reveals something of the international character of wisdom literature and the worldview of Proverbs. Frydrych (2002) states: 
The use of יהוה here denotes not so much that Yahweh, the God revealed in the Israelite cult, is the sages' God, but rather that the sages' God, witnessed in the world, is Yahweh, who also revealed himself in the cult. (p. 90)

Frydrych notes that the sages did not consider Yahweh to be a local deity, but rather that his influence was universal and could be discerned by peoples not partaking in Israel's cult. Thus, without deciding the debate of the mutual influence of the two ancient texts, Proverbs finds no problem at all in associating the teachings encapsulated in an Egyptian instruction, while at the same time emphatically identifying the God referred to in these teachings as Yahweh, the God revealed to Israel.

\section{Conclusion}

Brown (1999) rightly states that:

communities of faith have no option except to imagine themselves, informed by faith and understanding, living within the formative and normative contours of the biblical world ... a life guided by faithful and moral imagination. (pp. xi-xii)

Johnson (1998) calls it '[i]magining the world Scripture imagines.' In this enterprise, a Ricoeurian hermeneutic presents the readers of the biblical text with a helpful apparatus. Ricoeur is interested in the role of figurative texts in the formation of human subjectivity and understands religious studies to be a hermeneutical inquiry into the imaginative potential of myth, symbol, and story to aid human efforts to exist with integrity (Wallace 1995:14).

As discourse, ' $[m]$ etaphorical language is able to construct a new vision of reality' (Sandoval 2006:9). It has to do with the meaning of the text as reference (Ricoeur 1976:19-22). A text may not only be describing reality in a literal or empirically verifiable way, but through the literal meaning it may also come to a metaphorical meaning and actively be creating a symbolical world (Sandoval 2006:10).

Scott ([1989] 1990:47-48) asserts (in terms of narrative texts): 'At this second level, narrative is a model for re-describing reality. The mimesis of fiction is not a copy of reality but its re-description.' Ricoeur points out that the re-descriptive nature of biblical texts, or the operation of parabolisation, is not limited to those texts that are characteristically narrative, but is also at work in other literary genres (Ricoeur 1981:51) and can thus be applied equally well to Proverbs. The re-descriptive nature of biblical texts or operation of parabolisation is the operation of the biblical form of imagination (Ricoeur 1981:3-4).

Ricoeur (1976) therefore describes the poetic project as 'one of destroying the world as we ordinarily take it for granted ... $[t]$ o bring to language modes of being that ordinary vision obscures or even represses.' Wallace (1995:12) understands that:

The aim of an imaginative text is the creative imitation of human action - even as the purpose of metaphor ... is to re-describe the actual world in terms of possibility. (p. 60)
The text constructs, for the reader, a symbolic-textual world (Sandoval 2006:10). The structure of the world that the text projects in front of itself for the reader reveals the structure of reality (cf. Reese [1979] 1990:387).

In this way a text has the ability to 'change one's view of, or relationship to, reality' (Sandoval 2006:9). 'By virtue of its power to fuse the world of the text and the world of the reader' (Wallace 2000:305), the text draws the reader into the world that the text unfolds in front of itself (Ricoeur 1977:23).

Several scholars recognise that such a symbolic-textual reference is at work within the book of Proverbs. This is evident from the sample proverbs and can be illustrated from particular proverbs in each instance. For example, Sandoval (2006:6) affirms: 'Indeed the book of Proverbs constructs for its readers a complicated symbolic moral world.' This can especially be illustrated from Proverbs 10:27 where the proverb draws a close connection between the fear of the Lord and an increase of days, or conversely, wickedness and the shortening of years, with its implied understanding of divine activity. A complicated symbolic moral world is referenced by the text.

Ansberry (2011:125) concludes that Proverbs 'offer a fundamental moral vision that (re)constructs the addressee's perception of reality and shapes his character.' Proverbs 15:16 particularly demonstrates how the moral vision presented by the proverb has the ability to reconstruct the addressee's perception of reality and in the light of this re-described reality to affect the reader's character and actions.

From the prologue Frydrych (2002:32-37) construes that the explicit intention of the book is to make a wise person out of the immature by vividly painting the consequences of wisdom and folly. By sketching or painting the consequences of a choice between wisdom and folly to the reader's mental eye, the intention of the book is made clear. This observation is exemplified in Proverbs 14:26 where the consequence of the fear of the Lord is sketched vividly through the very concrete metaphor of a place of refuge. The positive consequence is textually expressed in synonymous parallelism illustrating the flow of the benefit of wisdom from one generation to the next.

Fox (2007) also observes the vivid illustrative character of the proverbs:

In fact, wisdom is an art, not a science, and the sages of wisdom are artists - הכמים, as artists are called in Exodus 36:4. The sages are artists painting a world whose realities often lie beneath the visible surface. (p. 684, [author's own emphasis])

This was hopefully sufficiently illustrated with the sample proverbs.

\section{Clifford (2009) notes:}

[T] he performance aspect of Proverbs, its orientation to decisionmaking, explains a remarkable feature of the book of Proverbs. It does not provide factual data, its instructions are notably empty of 'content,' and its maxims can seem trite if one expects new data. Rather, Proverbs' sayings give readers a perspective. (p. 243) 
It is this perspective or symbolical-textual world with specific reference to 'the fear of the Lord' that this article explored.

\section{Acknowledgements Competing interests}

The authors declare that they have no financial or personal relationship(s) which may have inappropriately influenced them in writing this article.

\section{Authors' contributions}

This article represents a reworked version of aspects from the PhD dissertation of A.V. (University of Pretoria, 2013), with P.M.V. (University of Pretoria) as supervisor.

\section{References}

Ansberry, C.B., 2010, 'What does Jerusalem have to do with Athens?: The moral vision of the book of Proverbs and Aristotle's Nicomachean ethics', Hebrew Studies 51 157-173.

Barton, J., 1996, Reading the Old Testament: Method in biblical study, Westminster John Knox Press, Louisville.

Boström, L., 1990, The God of the sages: The portrayal of God in the book of Proverbs, Almqvist \& Wiksell International, Stockholm.

Brown, W.P., 1999, The ethos of the cosmos: The genesis of moral imagination in the Bible, Eerdmans, Grand Rapids.

Brueggemann, W., 2003, An introduction to the Old Testament: The canon and Christian imagination, Westminster John Knox Press, Louisville.

Bullock, C.H., 2009, 'Wisdom, the "amen" of Torah', Journal of the Evangelical Theological Society 52(1), 5-18.

Clements, R.E., 2003, 'Proverbs', in J.D.G. Dunn \& J.W. Rogerson (eds.), Eerdmans commentary on the Bible, pp. 437-466, Eerdmans, Grand Rapids.

Clifford, R.J., 2009, 'Reading Proverbs 10-22', Interpretation 63, viewed 08 June 2012 from http://int.sagepub.com/content/63/3/242

Dell, K.J., 2006, The book of Proverbs in social and theological context, Cambridge University Press, Cambridge. http://dx.doi.org/10.1017/СBO9780511488306

Engelbrecht, B.J., 1978, 'Die betekenis van die begrip "vrees-van-die-Here" in Spreuke, Job en Prediker', in J.P. Oberholzer (red.), Teologie in die Kerk: Artikels en opstelle uit ' $n$ kwarteeu van teologiese arbeid, bl. 1-36, Haum, Pretoria.

Fox, M.V., 2004, 'The rhetoric of the disjointed proverb', Journal for the study of the Old Testament 29(2), 165-177. http://dx.doi.org/10.1177/030908920402900204

Fox, M.V., 2007, 'The epistemology of the book of Proverbs', Journal of Biblical Literature 126(4), 669-684.

Fox, M.V., 2009, Proverbs 10-31: A new translation with introduction and commentary, Yale University Press, New Haven.
Frydrych, T., 2002, Living under the sun: Examination of Proverbs and Coheleth, Brill, Leiden.

Garrett, D.A., 1993, Proverbs, Ecclesiastes, Song of Songs: The new American commentary, vol. 14, B \& H Publishing group, Nashville.

Hall, D.W., 2006, 'The economy of the gift: Paul Ricoeur's poetic redescription of reality', Literature \& Theology 20(2), 189-204. http://dx.doi.org/10.1093/litthe/ frl015

Heim, K.M., 2001, Like grapes of gold set in silver: An interpretation of proverbial clusters in Proverbs 10:1-22:16, de Gruyter, Berlin.

Ironside, H.A., 2006, Proverbs and Song of Solomon, Kregel, Grand Rapids.

Johnson, L.T., 1998, 'Imagining the world Scripture imagines', Modern Theology 14(2), 165-180. http://dx.doi.org/10.1111/1468-0025.00061

Loader, J.A., 1986, 'Tekste met 'n wysheidsperspektief', in F.E. Deist \& W.S. Vorster (reds.), Woorde wat ver kom, bl. 103-122, Tafelberg-Uitgewers, Kaapstad, http:// dx.doi.org/10.1111/1468-0025.00061

Murphy, R.E., 1998, Proverbs, Thomas Nelson, Nashville. (Word Biblical Commentary, vol. 22).

Reese, J.M., [1979] 1990, 'Can Paul Ricoeur's method contribute to interpreting the book of Wisdom?', in M. Gilbert (ed.), La sagesse de l'Ancien Testament, pp. 384396, Leuven University Press, Leuven.

Ricoeur, P., 1976, Interpretation theory: Discourse and the surplus of meaning, Texas Christian University Press, Fort Worth.

Ricoeur, P., 1977, 'Toward a Hermeneutic of the Idea of Revelation', Harvard Theological Review 70, 1-37. http://dx.doi.org/10.1017/S0017816000017600

Ricoeur, P., 1981, 'The Bible and the imagination', in H.D. Betz (ed.), The Bible as a document of the university, pp. 49-75, Scholars Press, California, viewed 28 February 2012, from http://www.fondsricoeur.fr/photo/Ricoeur\%20\%20The\%20 Bible\%20and\%20the\%20 Imagination.pdf

Ross, A.P., 2008, 'Proverbs', in L. Tremper \& D.E. Garland (eds.), Proverbs - Isaiah: The expositor's Bible commentary, Zondervan, Grand Rapids, viewed 16 June 2012, from http://0-books.google.co.za.innopac.up.ac.za/books?hl=en\&lr=\&id=j7xcbW grDxsC\&oi=fnd\&pg=PA11\&dq=proverbs+commentary\&ots=oGuLdlfsAb\&sig=zO kmAjXTFxo5xFPmFhRbsPJJgE\#v=onepage \& $q=$ proverbs\%20commentary \& $\mathrm{f}=$ false

Sandoval, T.J., 2006, The discourse of wealth and poverty in the book of Proverbs, Brill, Leiden.

Scott, B.B., [1989] 1990, Hear then the parables: A commentary on the parables of Jesus, Fortress Press, Minneapolis.

Shupak, N., 2005, 'The Instruction of Amenemope and Proverbs 22:17-24:22 from the perspective of contemporary research', in R.L. Troxel, K.G. Friebel \& D.R. Magary (eds.), Seeking out the wisdom of the ancients: Essays offered to honor Michael Fox on the occasion of his $65^{\text {th }}$ birthday, pp. 117-133, Eisenbrauns, Winona Lake.

Treier, D.J., 2011, Proverbs and Ecclesiastes: Brazos theological commentary on the Bible, Brazos Press, Grand Rapids.

Wallace, M.I., 1995, 'Introduction', in M.I. Wallace (ed.), Figuring the sacred: religion, narrative and imagination, transl. D. Pellauer, pp. 1-35, Fortress Press, Minneapolis. PMid:7709338

Wallace, M.I., 2000, ‘From phenomenology to Scripture? Paul Ricoeur's hermeneutical philosophy of religion', Modern theology 16(3), 301-313. http://dx.doi. org/10.1111/1468-0025.00129

Whybray, R.N., [1979] 1990, 'Yahweh-sayings and their context in Proverbs 10,122,16 ', in M. Gilbert (ed.), La sagesse de l'Ancien Testament, pp. 153-165, Leuven University Press, Leuven. 